\title{
FIELD EVALUATION OF SELECTED OXADIAZINE INSECTICIDE AND BACTERIAL BIO-INSECTICIDES AGAINST COTTON LEAFWORM, SPODOPTERA LITTORALIS (BOISDUVAL) (LEPIDOPTERA: NOCTUIDAE) INFESTING SUGAR BEET (BETA VULGARIS L)
}

\author{
YASMIN A. EL-FERGANI
}

Plant Protection Research Institute, Agriculture Research Center, Giza, Egypt. ORCID id: https://orcid.org/0000-0003-2661-7730

Corresponding e-mail: yasminelfergani@gmail.com

(Manuscript received 18 November 2018)

\begin{abstract}
I n the two successive growing seasons, 2017 and 2018, the efficacy of newer chemistry insecticide, Avaunt ${ }^{\circledR}$ (Indoxacarb) and a commercial bio-insecticide, Protecto $\AA$ (Bacillus thuringeinsis kurstaki) was evaluated in the field for management of Cotton leafworm, Spodoptera littoralis Boisd. in Egypt. The tested compounds were applied at the recommended dose proposed by Agricultural Pesticide Committee (APC). Sugar beet was cultivated at Talaat-El Agamy Farm, Shenno country, Kafr El-Sheikh Governorate. The sugar beet variety (Karam) was cultivated by the end of September during the two seasons in an area of about $1 \backslash 100$ fed. The field evaluation revealed that Avaunt ${ }^{\circledR}$ significantly reduced the larval population of $S$. littoralis compared to the untreated area. Protecto $\AA$ caused a significant reduction in insect infestation up to five days post treatment. Both Avaunt $\AA$ and Protecto $\AA$ can be used effectively by farmers as a component of integrated management of cotton leafworm in Egypt.

Keywords: Sugar beet, Indoxacarb, Bacillus thuringiensis, Spodoptera littoralis.
\end{abstract}

\section{INTRODUCTION}

Sugar beet (Beta vulgaris L.), is grown commercially for sugar production mostly in temperate countries (Rashid, 1999) due to its high sucrose content in root. In addition, this crop is considered to be a promising alternative energy source for ethanol production (BSRI, 2005). Sugar beet is used extensively in sugar industry in Egypt providing about $40 \%$ of the world sugar production and represents the second source, after sugar-cane. $55 \%$ of the annual cultivated area of sugar beet is concentrated in Kafr El-Sheikh Governorate (Abou El-Kassem, 2010). One of the most important pests that cause great damage to this economic crop is Spodoptera littoralis (Boisd.) which is known to be a polyphagous insect pest with numerous hosts that is widely distributed throughout the countries around the Mediterranean basin (Gómez de Aizpurua \& Arroyo, 1994) causing great destructive damage and economic loss in many outdoor and greenhouse horticultural crops (Bayoumi et al., 1998). In Egypt, due to the relatively high temperature throughout September, S. littoralis severely attack the seedlings of sugar beet causing large bare batches in the field and results in high 
economic losses (El-Mahalawy, 2011). The routine methods of chemical control using high doses of conventional insecticides making it is very difficult to suppress $S$. littoralis that has been developed high resistance to most of the currently used insecticides (Che et al., 2013) . On the other hand, it was recommended to use new chemistry insecticides that proved to be more preferable than conventional insecticides due to its novel mode of action with less eco-toxicity. Avaunt $®$ (Indoxacarb), a novel oxadiazine insecticide, is a new type of sodium channel blocker combined high activity, excellent selectivity, low residue and good field activity against a number of lepidopteran pests, as well as certain Homoptera and Coleoptera with no known cross-resistance to existing chemical groups (Wing et al., 2000, Ning et al., 2005). The commercial bio-pesticide, Bacillus thuringiensis, is one of the most widely used product since the discovery of microbial bio-pesticides to control insect pests in agriculture. It is considered to be one of the promising alternative to conventional insecticides as it is environmentally safe (Abd El-Salam et al., 2011). This work aimed to evaluate the efficiency of both Avaunt $\AA$ (Indoxacarb) and $B$. thuringiensis (Protecto $($ ) in controlling early infestation of $S$. littoralis to $B$. vulgaris under field conditions in Egypt.

\section{MATERIALS AND METHODS}

\section{Tested Insecticides}

1- Protecto $囚$, B. thuringeinsis var. kurstaki, (32000 I.U. /mg) WP was applied the rate of $300 \mathrm{gm} /$ feddan. The commercial biopesticides was obtained from the Bioinsecticide Production Unit, Plant Protection Research Institute, Agriculture Research Centre, Giza, Egypt.

2- Avaunt ${ }^{\circledR}$ (Indoxacarb, Carbamate: Oxadiazine, Acetylcholinesterase (AChE) inhibitors: Sod Channel blocker, 15 \% E.C., India).

\section{Study Site}

The experiment was conducted at the experimental farm of Talaat-El Agamy, Shenno country, Kafr El-Sheikh Governorate, Egypt.

\section{Field Trials}

The field trials was carried out in growing sugar beet infested with S. littoralis during the two successive planting seasons 2017 and 2018. The two field trials with the same treatments were carried out in each year. The local sugar beet variety (Karam) was used in all the experiments, and was cultivated by the end of September during the two seasons in an area of about 1/100 feddan in randomized complete block design. The area was divided into plots (each about $42 \mathrm{~m}^{2}$ ). Four plots were assigned for each treatment and for untreated area as well, two rows of plants were left untreated between plots. Applications were performed at the sunset using a knapsack motor 
sprayer (20 liters in capacity). The agricultural practices followed the recommendations of the Agricultural Pesticide Committee (APC). The tested insecticides were applied at the recommended field rate, while control plots were sprayed with water only. Examinations of 10 plants /plot /treatment were carried out just before the first application and after 1, 3 and five days after application of Avaunt $₫$ and after 2, 3 and five days after application of Protecto $\cap$. The efficiency of tested treatments was measured as a percentage of reduction in infestation density of $S$. littoralis larvae using Henderson and Tilton's formula (1955) as follows:

Reduction $\%=\left\{1-\frac{n \text { in Co before treatment } x \text { in } T \text { after treatment }}{n \text { in Co after treatment } x \text { in } T \text { before treatment }}\right\} \times 100$.

$\mathrm{n}$ : Insect population, $\mathrm{T}$ : treated , Co: control

\section{Statistical Analysis}

Data were presented as mean number of collected insects/ treatment and percent reduction in infestation. Statistical analysis between means were done using analysis of variance (ANOVA) at $p=0.05$ using Minitab v. 16 software.

\section{RESULTS AND DISCUSSION}

The efficiency of both Avaunt $₫$ (Indoxacarb) and Protecto ${ }^{\circledR}$ (B. thuringiensis) were evaluated in field trials for suppressing $S$. littoralis larvae population in early sugar beet infestation during two successive seasons, 2017, 2018. The number of larvae of cotton leafworm was recorded before and after treatments and the reduction percentage was calculated. The data in Table $(1 \& 2)$ represents the mean number and reduction percentage of $S$. littoralis larval population in sugar beet field after treatment with the tested insecticides during 2017season. Under field conditions, it was noticed that Avaunt $\AA$ was effective against $S$. littoralis larvae one day post treatment compared to untreated area causing nearly $75 \%$ reduction. Protecto $\AA$ showed significantly reduction percentage after 2,3 and 5 days that ranged from $53.74 \%$ to $64.20 \%$ compared with untreated area. After three days the reduction percentage post treatment with Avaunt $\AA$ (83.13\%) was significantly higher than that treated with Protecto ${ }^{\circledR}(56.02 \%)$ and with untreated area. After five days Avaunt $\AA$ showed significant reduction percentage $(85.57 \%)$, the time that Protecto $®$ caused $64.02 \%$ reduction percentage. The overall reduction of $S$. littoralis larvae population after treatment with Protecto $尺$ in season 2017 was $57.92 \%$ (Fig. 1) while Avaunt $®$ showed overall reduction $81.34 \%$. In Table (3\&4), the obtained data represents the mean number and reduction percentage of $S$. littoralis larvae treated with the tested insecticides in season 2018. The reduction percentage in cotton leafworm larval population in season 2018 was less than in 2017.The obtained data showed Avaunt ${ }^{\circledR}$ caused $74.11 \%$ reduction percentage in the pest population after 1 day that reached that reached $79.74 \%$ after three days compared to the untreated area. While, 
Protecto $\AA$ achieved about $65.15 \%$ reduction percentage after three days post treatment. It is clear from Tables (1\&2) that the highest reduction percentage was observed after 5 days post treatment in case of both Protecto $\AA$ (64.02) and Avaunt $\AA$ $(85.57 \%)$ in season 2017. Fig. 1 showed the overall reduction of the infestation with $S$. littoralis that was significantly increased during both 2017 and 2018 seasons, after treatment with the tested insecticides. The obtained results showed that the bacterial $(B t)$ bio-pesticides offer an excellent safe bio control methods in controlling early infestation of $S$. littoralis and should be included in IPM programs with selected insecticide groups. The same findings were obtained by Hanafi (1999) who mentioned that biological control program in particular was more effective in preventing damage by pests in cases where the initial level of infestation was relatively low. Radwan et al. (2004) discussed the possibility of using bio-pesticides (Xentari) for controlling $S$. littoralis and they found that these materials may not cause any kind of pollution to the environment and natural enemies. The obtained results in this study showed that Protecto ${ }^{\circ}$ after five days achieved high reduction percentage $(56.02 \%)$ and this was in agreement with El -Zoghbey et al. (2003) who found that biocides, Agerin (Bt) caused a reduction in $S$. littoralis population at three concentrations applied in the field on sugar beet. Also, Said et al. (2012) mentioned that the residual effect of Protecto $®$ recorded $77.05 \%$ of reduction percentages in S. littoralis in sugar beet fields, While El-Samahy (2015) clarified that the (Bt) bio-insecticide (Dipel 2X) showed low efficacy in controlling the cotton leafworm, $S$. littoralis in sugar beet field. Many studies found that $B t$ bioinsecticides reduced greater sugar-cane borer; Sesamia cretica (Lederer) infestation in the field and can be an excellent alternatives for chemical insecticides in control program (Salem, 2011). During the investigation, the data revealed better efficacy of Avaunt $\AA$ (Indoxacarb) against S. littoralis in both seasons, 2017 and 2018. Similar findings on the efficacy of Indoxacarb against this pest has been previously reported (Gamil et al., 2011). El-Dewy 2013 found that indoxacarb is highly effective against cotton leaf worm, S. littoralis. Also, Saimandir and Gopal (2012) discussed the efficacy of Avaunt ${ }^{\circledR}$ against this pests infesting Eggplant (Solanum melongena L.) even at lower dose and cleared that the application of Indoxacarb at recommended dose could enhance the Eggplant yield. The efficacy of Indoxacarb was studied also against other lepidopterous pests as Fruit borer, Leucinodes orbonalis (Guen.) (Patra et al., 2009). Indoxacarb as an oxadiazine insecticides can be used as a good tool for pest control programs in field applications and emphasized the deduction of Wing et al. (2000) who deduced that Indoxacarb can be proposed as good field activity insecticide against some lepidopterous pests, as well as, some Homptera and Coleoptera because it is characterized with their unique modes of action, they have the potential for crop 
protection against economic pests and low toxicity to environment components and natural enemies.

This present study revealed that Avaunt $\AA$ as novel insecticides and Protecto $\AA$ as commercial bioinsecticides were highly effective against early stages of $S$. littoralis larvae that infested sugar beet fields in Egypt and could be used in IPM programs.

Table 1 . The mean number of $S$. littoralis larvae in sugar beet field before and after treatment with the tested insecticides during 2017season.

\begin{tabular}{|l|l|l|l|l|l|}
\hline Treatments & $\begin{array}{c}\text { Before } \\
\text { treatment }\end{array}$ & Mean \pm SD & Mean \pm SD & Mean \pm SD & Mean \pm SD \\
\cline { 3 - 6 } & & 1 DAY & 2 DAYS & 3 DAYS & 5 DAYS \\
\hline Protecto $®$ & $12.25 \pm 1.7 \mathrm{a}$ & & $7.00 \pm 2.7 \mathrm{~b}$ & $7.50 \pm 1.29 \mathrm{~b}$ & $7.0 \pm 2.07 \mathrm{~b}$ \\
\hline Avaunt $®$ & $12.00 \pm 1.4 \mathrm{a}$ & $3.25 \pm 1.2 \mathrm{~b}$ & & $2.50 \pm 1.29 \mathrm{c}$ & $2.75 \pm 0.9 \mathrm{c}$ \\
\hline Untreated area & $12.75 \pm 3.9 \mathrm{a}$ & $14.00 \pm 1.4 \mathrm{a}$ & $15.75 \pm 3.7 \mathrm{a}$ & $17.75 \pm 3.09 \mathrm{a}$ & $20.25 \pm 2.0 \mathrm{a}$ \\
\hline
\end{tabular}

*SD = Standard deviation.

**Means in a column sharing the same letter are not significantly different at $\mathrm{P}<0.05$.

Table 2. Reduction percentage of $S$. littoralis larvae in sugar beet field after treatment with the tested insecticides during 2017 season.

\begin{tabular}{|l|l|l|l|l|}
\hline \multirow{2}{*}{ Treatments } & Reduction $\%$ & Reduction $\%$ & Reduction $\%$ & Reduction $\%$ \\
\cline { 2 - 5 } & 1 DAY & 2 DAYS & 3 DAYS & 5 DAYS \\
\hline Protecto $®$ & & $53.74 \%$ & $56.02 \%$ & $64.02 \%$ \\
\hline Avaunt $\AA$ & $75.33 \%$ & & $83.13 \%$ & $85.57 \%$ \\
\hline
\end{tabular}

Table 3. The mean number of $S$. littoralis larvae in sugar beet field before and after treatment with the tested insecticides during 2018 season.

\begin{tabular}{|l|l|l|l|l|l|}
\hline Treatments & $\begin{array}{c}\text { Before } \\
\text { treatment }\end{array}$ & Mean \pm SD & Mean \pm SD & Mean \pm SD & Mean \pm SD \\
\cline { 3 - 6 } & & 1 DAY & 2 DAYS & 3 DAYS & 5 DAYS \\
\hline Protecto $®$ & $11.00 \pm 1.8 \mathrm{a}$ & & $9.50 \pm 2.08 \mathrm{~b}$ & $8.25 \pm 2.5 \mathrm{~b}$ & $6.0 \pm 2.1 \mathrm{~b}$ \\
\hline Avaunt $尺$ & $10.25 \pm 1.7 \mathrm{a}$ & $3.00 \pm 1.8 \mathrm{~b}$ & & $3.75 \pm 1.7 \mathrm{~b}$ & $3.25 \pm 0.95 \mathrm{~b}$ \\
\hline $\begin{array}{l}\text { Untreated } \\
\text { area }\end{array}$ & $11.50 \pm 1.9 \mathrm{a}$ & $13.0 \pm 0.8 \mathrm{a}$ & $14.00 \pm 3.6 \mathrm{a}$ & $15.75 \pm 4.3 \mathrm{a}$ & $18.00 \pm 2.1 \mathrm{a}$ \\
\hline
\end{tabular}

$* \mathrm{SD}=$ Standard deviation.

**Means in a column sharing the same letter are not significantly different at $\mathrm{P}<0.05$. 
FIELD EVALUATION OF SELECTED OXADIAZINE INSECTICIDE AND BACTERIAL BIO-INSECTICIDES AGAINST COTTON LEAFWORM, SPODOPTERA LITTORALIS (BOISDUVAL) (LEPIDOPTERA: NOCTUIDAE) INFESTING SUGAR BEET (BETA VULGARIS L)

Table 4. Reduction percentage of $S$. littoralis larvae in sugar beet field after treatment with the tested insecticides during 2018 season.

\begin{tabular}{|l|l|l|l|l|}
\hline \multirow{2}{*}{ Treatments } & Reduction $\%$ & Reduction $\%$ & Reduction $\%$ & Reduction $\%$ \\
\cline { 2 - 5 } & 1 DAY & 2 DAYS & 3 DAYS & 5 DAYS \\
\hline Protecto $®$ & & $29.06 \%$ & $45.24 \%$ & $65.15 \%$ \\
\hline Avaunt $®$ & $74.11 \%$ & & $73.29 \%$ & $79.74 \%$ \\
\hline
\end{tabular}

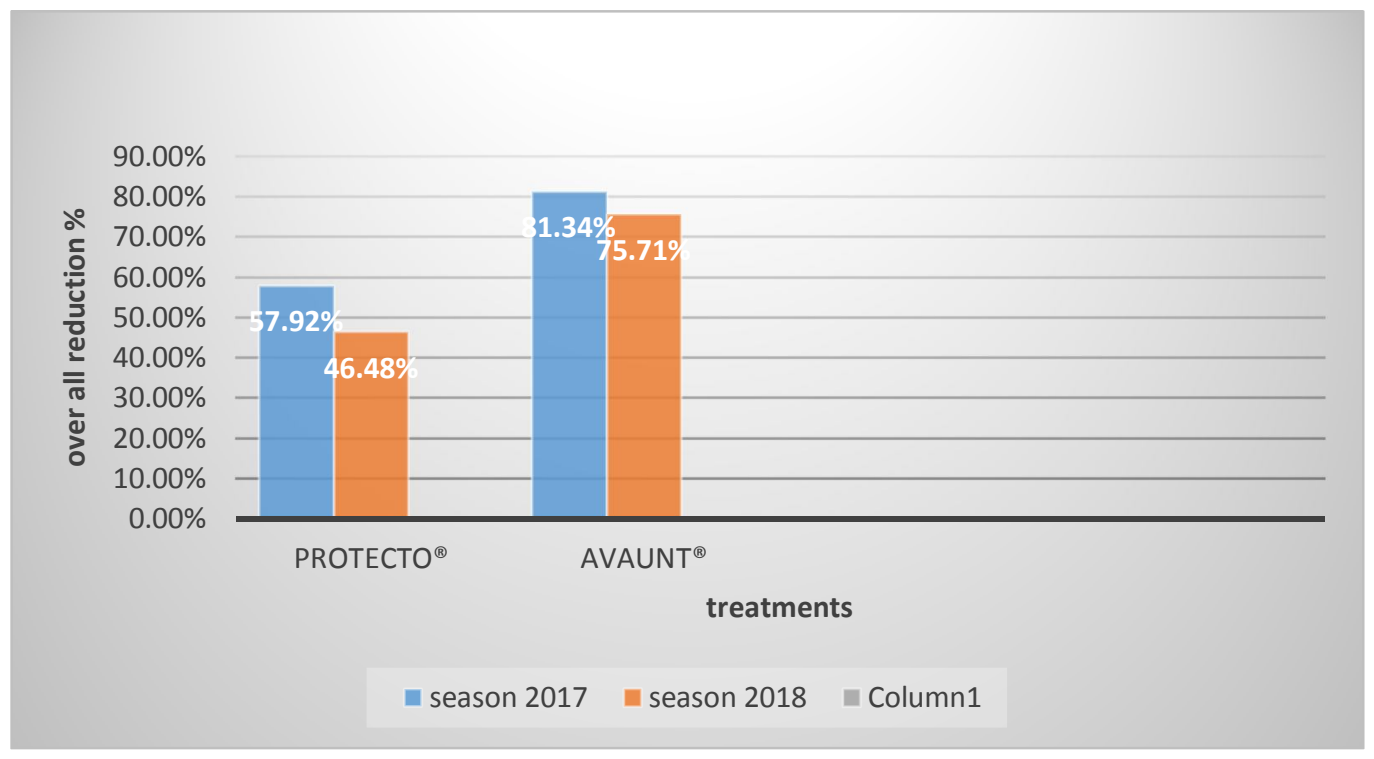

Fig.. 1. Assessment of overall reduction caused after treatment with the tested insecticides against S. littoralis larvae in sugar beet field during 2017, 2018 seasons.

\section{REFERENCES}

1. Abd El-Salam, A. M., A. M. Nemat, and A. Magdy. 2011. Potency of Bacillus thuringeinsis and Bacillus subtilis against the cotton leafworm, Spodoptera littoralis (Boisduval) larvae. Archi. Phytopathol. Plant Protec., 44(3) 204-215.

2. Abou-El-Kassem, A. B. 2010. Ecological and biological studies on some insects of sugar beet plants at Kafr El-Sheikh governorate. Ph.D. Thesis, Fac. Agric., Kafr ElSheikh Univ., pp. 221.

3. Bayoumi, E., R. Balaña-Fouce, K. Sobeiha, and M. K. Hussin. 1998. The biological activity of some chitin synthesis inhibitors against the cotton leafworm Spodoptera 
littoralis (Boisduval) (Lepidoptera:Noctuidae). Boletin de Sanidad Vegetal Plagas, 24: 499-506.

4. Bangladesh Sugar beet Reasearch Institute (BSRI) 2005. Sugar beet cultivation in Bangladesh. Bangladesh Sugarcane Res. Instit., Ishurdi. P. 10.

5. Che, W., T. Shi, Y. Wu and Y. Yang. 2013. Insecticide resistance status of field populations of Spodoptera exigua (Lepidoptera: Noctuidae) from China. J. Econ. Entomol. 106 (4):1855-1862.

6. El -Zoghbey, A. A., F. A. Atalla and A. H. Mesbah. 2003. Effect of two biocides in controlling Cassida vittata (Vill.) and Spodoptera littoralis (Boisd.) infesting sugar beet plants. Ann. Agric. Sci., Moshtohor.

7. El-Dewy, M. E. H. 2013. Biological, Toxicological Potency and Field Persistence of New Insecticides against Spodoptera littoralis (Boisduval). Alex. Sci. Exchange J., 34(3):306-315.

8. El-Mahalawy, N. A. 2011. Ecological and biological studies on some sugar beet insects. M. Sc. Thesis, Fac. Agric., Tanta Univ. 178pp.

9. El-Samahy, M. F. M., I. F. Khafagy and A. M. A. El- Ghobary. 2015. Efficiency of silica nanoparticles, two bioinsecticides, peppermint extract and insecticide in controlling cotton leafworm, spodoptera littoralis Boisd. and their effects on some associated natural enemies in sugar beet fields. J. Plant Protec. Pathol. Mansura Univ., 6(9): 1221-1230.

10. Gamil, W. E., F. M. Mariy, L. A. Youssef and S. M. Abdel Halim. 2011. Effect of Indoxacarb on some biological and biochemical aspects of Spodoptera litoralis (Boisd) larvae. Ann. Agric. Sci., 56(2): 121-126.

11. Gómez d'Aizpurua, C. and M. Arroyo. 1994. Principales noctuidos actuales de interés agrícola. Edifur, S. A. Madrid, España, 145.

12. Hanafi, A. 1999. Integrated pest management of potato tuber moth in field and storage. Potato Res., 42(2):373-380.

13. Henderson, C. F. and E. W. Tilton. 1955. Tests with acaricides against the brown wheat mite. J. Econ. Entomol. 48: 157-161.

14. Ning, D., Q. Meng, W. Zhao and W. Miao. 2005. Progress on Indoxacarb as an Oxadiazine Insecticide. Chinese J. Pestic. Sci. 2005-2. 
15. Patra, S., M. L. Chatterjee, S. Mondal and A. Samanta. 2009. Field evaluation of some new insecticides against brinjal shoot and fruit borer, Leucinodes orbonalis (Guen.). Pestic. Res. J., 21(1): 58-60.

16. Radwan, S. M. E., F. F. Shalaby, E. H. Abd El-Karim, and E. S. Mansour. 2004. The simultaneous effect of certain recommended insecticides and selective biocides on the changes in the population density of cotton leafworm and its related bio agents inhabiting cotton fields. Egypt. J. Agric. Res., 82 (3): 1139-1153.

17. Rashid, M. M. 1999. Sabji Biggan (in Bengali), Rashid Publishing House, 94, Old DOHS, Dhaka. P. 455.

18. Said, A. A. A., F. A. H. Shaheen, E. A. H. Sherief and H. A. M. Fouad. 2012. Estimation of certain compound against cotton leafworm, spodoptera littoralis (Boisd.) on sugar beet plants. J. Plant Protec. Pathol., Mansoura Univ., 3 (12): $1321-1330$.

19. Saimandir, J. and M. Gopal. 2012. Evaluation of Synthetic and Natural Insecticides for the Management of Insect Pest Control of Eggplant (Solanum melongena L.) and Pesticide Residue Dissipation Pattern. Am. J. Plant Sci., 3: 214-227

20. Salem, S. A. R. 2011. Studies on the effect of Bacillus thuringiensis as a microbial control agent against the greater sugar-cane borer, Sesamia cretica (Lederer). M. Sc. Thesis, Fac. Sci. (Qena), South Valley Univ., 122pp.

21. Wing, K. D., M. Sacher, Y. Kagaya, Y. Tsurubuchi, L. Mulderig, M. Connair and M. Schnee. 2000. Bioactivation and Mode of Action of the Oxadiazine Indoxacarb in Insects. Crop Protec., 19: 537-545. 


\section{التقييم الحقلي لإحدى مبيدات الأوكساديازين والمبيدات الحيويه البكتيرية ضد دودة ورق القطن الكبرى التي تصيب بنجر السكر}

$$
\text { ياسمين عادل علي فرجاني }
$$

$$
\text { معهد بحوث وقاية النباتات - مركز البحوث الزراعبه - دقي- جيزه }
$$

تم تقييم إحدى مبيدات الأوكساديازين الأفانت (الإندوكسي كارب) و المبيدات الحيويه البكتيريه (البروتكتو) تجاه دوده ورق القطن الكبرى التي تصيب بنجر السكر في مصر في موسمين حقليين متتاليين 2017و 2018 في إطار در استهم من أجل الوصول لتطبيق حقلي فعال في المكافحة المتكامله في الظروف البيئيه المصريه. وتم إجر اء المعاملات الحقليه بالجر عات الموصى بها من وز ارة الزر اعه. تم إجر اء الدراسه في مزرعة طلعت العجمي، قرية شنو، محافظة كفر الثيخ ـ تم إجر اء المعاملات

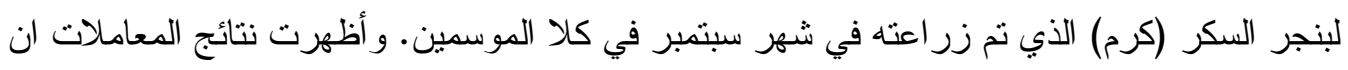
مبيد الأفانت تسبب في خفض ملحوظ في تعداد الحشرات في الحقل مقارنة بالمنطقه الني لم يتم معاملتها بأي مبيد. كما أظهر المركب الحيوي البروتكتو خفض نر اكمي بعد خمس أيام من المعامله. كما توصي الدراسة بإدر اج مركبي الأندوكسي كارب و البرتكتو ضمن خطط المكافحة المتكامله لهذه

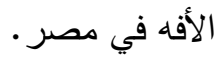


